\title{
Iowa at Vicksburg: Breaking Boundaries
}

\author{
Eric Kniel \\ University of Iowa \\ Originally written for Professor Douglas Baynton
}

16A:051 Colloquium for History Majors 
In typical popular history, the American Civil War is told in fundamentally black and white terms. The North versus the South, Yankees versus Rebels- these are the phrases we so often hear, and all while following a strict geographical line of the Mason-Dixon, dividing the country in two. We also hear of the great, yet terrible battles that occurred during the war, with fantastic tales of bravery and cowardice, glory, and disgrace. However, there was more to one of the greatest wars in American history than such narrow lines of thought. The Iowa regiments' involvement leading up to and through the Siege of Vicksburg, and their versatility during this time, shows an aspect of the Civil War that is normally lost in the popular histories of the conflict as a whole. By viewing the experiences of these men, we can see that all soldiers did so much more work during the course of the overall war than just fighting. These less romanticized efforts off the battlefield many times proved to be just as important as the work on the battlefield. These Iowa regiments and their experiences also show that the war was not so narrowly North versus South, but much more regional. All of these seemingly mundane aspects of versatility and regional issues of family and home are left out of the popular histories of today's world. But we can use Vicksburg as an example to show how these aspects truly did apply to all soldiers during the entire war.

The Vicksburg Campaign was a series of battles between the Union and Confederate forces, beginning in December of 1862 and ending with the eventual capture of the city of Vicksburg itself on July 4, 1863. This was a massive victory for the Union, as it then controlled the entire Mississippi River, cutting the Confederacy in two. This also opened up the Mississippi for supply routes and transportation, both which were vital to the Union. The Union forces were led by Ulysses S. Grant, who would later be known as the hero of the war for his leadership and role in the Union victory. During this campaign, Grant controlled the Army of the Tennessee, 
which was composed of almost completely of Midwestern regiments. ${ }^{1}$ Most of the soldiers in the regiments during this campaign, as well as most all regiments in the Civil War, were not just from the same state, but many from the same county and even the same town. During the siege of the city itself, conditions were harsh. As one soldier described his experience, "Ball and shell [come] into camp every day... shell has been bursting just at the top of the hill above us (we are in a hollow). Balls and pieces of shell fall into our camp every few moments...”2 Another soldiers wrote, "Bullets fly thick over our heads. The shells burst over us sometimes.”3 These are the experiences and events that we are accustomed to hearing about when it comes to Vicksburg: the two main assaults on the city on May $19^{\text {th }}$ and $22^{\text {nd }}$ and the forty-four day siege that immediately followed. But the two assaults and the siege itself could not have happened and would not have happened if not for the work of thousands of brave soldiers off the battlefield. By focusing on the Iowa regiments that participated in the campaign and the Siege of Vicksburg, one can see the impact of the less glorious tasks of war, carried out everyday by thousands of soldiers throughout the entire war, that were necessary for the great battles to even occur.

General Ulysses S. Grant and his Army of the Tennessee reached the city of Vicksburg and immediately began preparing for an assault. Grant believed that the Confederates "had been much demoralized by” their defeats in earlier battles in the campaign. Furthermore, he believed his forces could storm the Confederate works and take the city fairly easily. ${ }^{4}$ Even before the first assault began, the Iowa soldiers were helping secure the surrounding area for the assault force. General William T. Sherman, commander of the XV Corps of Grant's army, was

\footnotetext{
${ }^{1}$ Edwin Cole Bearss, The Vicksburg Campaign (Dayton: Morningside House Inc., 1986), Vol. 3: 773-78, 862-69, 957-63.

${ }^{2}$ William A. Russell to Juliet Russell, June 19, 1863, Russell Family Papers, Civil War Collection, Special Collections Dept., University of Iowa Libraries, Iowa City, IA.

${ }^{3}$ Joseph Kohout to his father, June 4, 1863, Joseph Kohout Letters, Civil War Collection, Special Collections Dept, University of Iowa Libraries, 423Iowa City, IA.

${ }^{4}$ Bearss, 761 .
} 
concerned with the possibility of one of his divisions meeting harsh resistance from Confederate forces before reaching their attack point at Walnut Hills. On the morning of May $19^{\text {th }}$, he sent the third brigade of his third division, a brigade of three Iowa regiments, to scout out the area on a plantation road that split off to the west from Benton Road. Under General Matthies, the Iowa regiments advanced along the plantation road and accessed the River road to Yazoo City with no resistance. After hearing this, Sherman ordered the brigade to retrace its steps back to where it had originally started. By noon on the $19^{\text {th }}$, the brigade had returned after marching ten difficult miles. $^{5}$

The first assault began and the Union army soon realized that it would not be easy to take Vicksburg. During the assault, Sherman was informed of a critical ammunition shortage for his forces on the front lines. Sherman quickly asked for volunteers from his rear forces to take the heavy boxes of ammunition to the front. Immediately, the men of Company C of the Iowa $12^{\text {th }}$ Volunteer Regiment stepped forward. Soon, ammunition was flowing in great amounts to the front, "carried on the backs of the husky Iowans." ${ }^{\prime 6}$ These Iowans risked their lives to get the ammunition to their fellow soldiers at the front lines, showing great courage and character.

Though the first assault would eventually fail, the effort and commitment that the Iowa regiments had towards seemingly boring and unglamorous tasks during the day of the $19^{\text {th }}$ made the assault possible. Without the $12^{\text {th }}$ Iowa, Sherman's forces would have exhausted their ammunition, ending all chances of victory that day and causing many more casualties for the Union soldiers. Had Matthies’ brigade not marched ten rugged miles in a few short hours and scouted ahead that morning, Sherman would not have known what his attacking force was to face before reaching their launching point for the assault, which could have led to disaster for the

\footnotetext{
${ }^{5}$ Ibid, 756-57.

${ }^{6}$ Ibid, 766.
} 
Union if Confederate troops had actually occupied the area. Though the Iowa regiments' casualties (killed, wounded and missing) as a whole that day were 52, which was low compared to many other regiments involved on this day, the Iowans proved that there is much more to any battle than just fighting it. ${ }^{7}$ Their grunt work and behind the scenes proved vital to the operations of the first assault, just as these efforts are to any and all battles.

After the failure of the first assault, the Union high command, including Grant, thought that a siege would be the best strategy for taking the city. Despite this belief, Grant decided to assault the city one final time, and set the date for May $22^{\text {nd }} .8$ Before the assault even began, Union artillery shelled the Confederate entrenchments. General Sherman believed that a main reason that his force's first assault on Stockade Redan (the Confederate work they had been assigned to overtake) had failed was due to lack of artillery support and preparation. This time, Sherman sent orders to begin digging artillery entrenchments and roads for the transport of artillery in advance. Many Iowa regiments were involved, but Matthies' brigade $\left(8^{\text {th }}, 12\right.$ th and $35^{\text {th }}$ Iowa regiments, under Tuttle's $3^{\text {rd }}$ Div.), along with the rest of their division, were so close to the enemy lines that they had to be protected by another division of sharpshooters and scouts ( ${ }^{\text {nd }}$ Div.). These soldiers risked being shot at any time while they dug rifle-pits and constructed artillery parapets to prepare for the second assault. ${ }^{9}$ As a result, the artillery regiments had a significant impact on the Confederate positions, even before the assault began. The $2^{\text {nd }}$ Iowa Battery was part of this group of artillery that backed up Sherman's troops. Confederate General Shoup and his men were the Confederate forces defending the Stockade Redan area, and he complained to the commanding general at Vicksburg, General Pemberton, about the Union artillery barrage. Shoup claimed that his artillery was "all but useless" and that the enemy

\footnotetext{
${ }^{7}$ Bearss, 775-78.

${ }^{8}$ Ibid, 787.

${ }^{9}$ Bearss, 793.
} 
artillery was knocking his parapets apart faster than his men could repair them. Soon, however, the Union artillery began to wane and almost completely ceased firing - the Federals ran out of ammunition from firing so much, and had to wait until more could be brought up before they could continue the barrage. ${ }^{10}$

In another part of the battlefield, Iowa regiments in the XIII Corps, $14^{\text {th }}$ Division, under General Carr, moved into position near the 2d Texas Lunette, another Confederate work. These regiments were sent to reinforce and relieve troops under General A.J. Smith, who had been moving forward to establish Union lines. On the night of the $20^{\text {th }}$, Carr's men (with two Iowa regiments) began digging rifle-pits in preparation for the next-day’s assault. “Carr’s men dug like badgers all that night, and when dawn arrived on the $21^{\text {st }}$, the Texans in the Rebel works were astonished to find a line of rifle-pits extending almost continuously across their front."11

As these regiments worked on preparations for the assault, another group of Iowans were working to secure the rest of the area around Vicksburg. General Hall's third brigade of the sixth division of the XVII Corps was originally ordered to reunite with the rest of its division located at Snyder’s Bluff. The Iowans loaded up onto steamboats and were transported to Bowers' landing, where they unloaded and began a march across De Soto Point to Young’s Point; from there, on the morning of the $21^{\text {st }}$, they were transported to Snyder's Bluff. As they pulled into Snyder's Bluff landing, however, they received new orders to land at Warrenton and seal off the southern approaches to Vicksburg. Warrenton Road led directly into the city. They had to retrace their steps back to Bowers’ Landing, which did not sit well with most of the troops. The reason they were sent to Warrenton was to occupy the Confederate forces in the southern part of the city to prevent them from reinforcing the other Confederate units defending the works targeted by the

\footnotetext{
${ }^{10}$ Ibid, 794.

${ }^{11}$ Ibid, 801
} 
Union assault. If the Rebels did weaken their defenses in this southern part of the city, Hall's brigade was to enter the city. This played a key role in containing more Confederate forces and putting more pressure in different places during the assault.

The Iowans reached their positions during the afternoon of the $21^{\text {st }}$, and on the $22^{\text {nd }}$ began to advance towards South Fort, the southern fortifications of the city. Infantrymen from the $11^{\text {th }}$, $13^{\text {th }}$ and $16^{\text {th }}$ Iowa regiments were chosen as sharpshooters to protect the rest of the brigade as it moved forward. As they reached the South Fort area, they began to prepare to storm the enemy works. But before division commander General McArthur gave the order, a new order was received to reinforce General McClernand's force, which was part of the main assault. The Iowans then began a very long march to reach their newly ordered positions, but would eventually get there too late to be of use. ${ }^{12}$ These Iowa soldiers role off the battlefield was pivotal, and they did whatever was asked of them, no matter how frustrating, to help protect and eventually reinforce the rest of the assaulting force.

These regiments all were vital in the preparations for the assault on Stockade Redan and the $2 \mathrm{~d}$ Texas Lunette, as well as securing the southern area of the city; just as many of the other regiments' participating in the assault did things beforehand that were vital to the assault as a whole. All of these preparations were absolutely necessary for the second attempt to take the city to even begin, let alone succeed. Similar preparations were necessary not just for the first and second assaults at Vicksburg, but also for every battle that occurred during the war. Different battles called for different preparations, of course, but the overall concept remains the same. The fighting was the end result, but the many and at times tedious preparations that had to be made before the fighting were just as important as the battle itself, if not more so. Without someone to dig artillery parapets, there can be no artillery support, and without someone to dig rifle-pits,

\footnotetext{
${ }^{12}$ Bearss, 805-06, 856-57.
} 
there can be no protection for attacking troops. These seemingly small things, the labor and grunt work, too often go unrecognized by the traditional histories of the Civil War. But the fact is, there could be no battle, no glorious tales of fighting and dying without the numerous tasks that were completed before it, sometimes inviting the soldiers' frustration. These brave men proved their worth as soldiers by doing what they were told, even if they found it useless or personally disagreed with the order. So many of these men would eventually fight and thousands of them died on the famous and infamous battlefields that spread across the southern terrain of the divided nation. But so many more men were the backbone of these operations, and too many times go unrecognized for their valiant efforts.

Another aspect of the war that traditional history fails to accurately grasp and describe is how regionally defined the war really was. It was not uncommon for a soldier to be fighting next to his neighbor or even his own brother during a battle, and this made each battle that much more significant to each and every soldier. Much of this can be seen in soldiers' letters to and from home and in their diaries that many kept, some throughout the entire war. "The neighbor boys are all well,” one soldier wrote, reporting back to his family at home in Iowa, showing obvious care for those from his town and neighborhood. ${ }^{13}$ The war was also fought on American soil, making it unlike any other major American war other than the American Revolution. Many of these soldiers truly were defending their homes and homeland in the literal sense. These factors made the war much different than traditional history's boundaries claim. Campaigns, such as Vicksburg, and individual battles were much more specific to regions, and therefore were much more complex than just North versus South. During Vicksburg, the Union forces were almost exclusively from Illinois, Ohio, Wisconsin, Missouri, Michigan, Minnesota, Indiana, and of

\footnotetext{
${ }^{13}$ James Giauque to Alfred Giauque, June 23, 1863, Giauque Family Papers, Civil War Collection, Special Collections Dept., University of Iowa Libraries, Iowa City, IA.
} 
course Iowa. ${ }^{14}$ The presence of these troops underscores that Vicksburg was a much more regional, Midwestern affair. For example, Missouri was divided in two, as it had regiments in both the Union and Confederacy. This meant that some soldiers could be fighting a person or even a family member from the same town. Fighting with your brother is one thing, but fighting against him is a whole different issue. This was common throughout the war in all different regions, and this is why each campaign and each battle was so regional. In each battle, soldiers represented their specific side, but they fought for their brother or neighbor next to them and for their family and friends back home.

The importance of the soldiers' family and homes comes across in the letters soldiers received from family and friends. Many soldiers' would spend vast amounts of the free time they had writing home to their mothers, fathers, children, or friends. And because of this, they expected, and even needed to receive letters back, informing them of how things were on the home front. These letters many times would get a soldier through the day, especially in regard to the terrible things most of the soldiers were forced to see and experience. "I haven't had a letter from you and Sallie for a long time," one Iowa soldier wrote home, "I want to hear from you and Sallie the worst kind."15 Family and home were incredibly important to these soldiers, and letters played a key role in getting information back and forth. The significance of home was evident in other ways. As Asahel Mann, of the $4^{\text {th }}$ Iowa Cavalry said in his letter to his eventual wife Jennie, "It looks very hard to see our friends buried so far from home in a strange country." ${ }^{\text {16 }}$ Soldiers cared very deeply about their hometown and home state, which led to them fighting more for that hometown and state, and the family and friends they left behind. The more

\footnotetext{
${ }^{14}$ Bearss, 773-78, 862-69, 957-63.

${ }^{15}$ Asahel Mann to his mother, May 31, 1863. Papers of the Mann Family, Civil War Collection, Special Collections Dept, University of Iowa Libraries, Iowa City, IA.

${ }^{16}$ Asahel Mann to Chloe Jane (Jennie) Scott, June 20, 1863, Papers of the Mann Family.
} 
broad issues of the Civil War, such as slavery, of course played a role, but more prominently in the South. For many of these soldiers, protecting those they loved and the land they loved was the main motivator and almost always on their minds.

Soldiers also showed their allegiance to their region by their love for their commanding officers. The officer in charge of a regiment or brigade was most likely much more popular with his specific soldiers than the commander of the division or the corps, because the regimental officer was almost always from the same place as the regiment. This was much more common in the Civil War than later on, because in subsequent wars regiments were filled with soldiers and officers from all over the country. Soldiers in all wars usually are more attached to regimental commanders due to those commanders being more familiar and being with them every day, but this was even more so since the officer was also from the same area if not same town as the rest of the troops. During the Siege of Vicksburg, Iowa regiments were often ordered to march somewhere or do something, only to get to that place and be ordered to turn around and go back to where they started. Matthies' brigade and their scouting mission, along with Hall's brigade and their sealing off the southern approaches to Vicksburg, which were both during the second assault, illustrate this. During these times, the soldiers would often question the ability of their commanding officers (the higher up ones, such as Grant) to “make up their minds,” but would still push on, following the lead of their own brigade or regiment commander. ${ }^{17}$ In some instances, higher-up commanders were very popular with the soldiers from their home state, again showing the importance of region. General Francis J. Herron moved to Dubuque, Iowa in 1855 from Pennsylvania. He eventually joined the Union army and was commissioned captain of the $1^{\text {st }}$ Iowa regiment, then rose to lieutenant colonel in the $9^{\text {th }}$ Iowa for his services at Wilson's Creek. He then rose to brigadier general after the Battle of Pea Ridge in 1862, where he was

\footnotetext{
${ }^{17}$ Bearss, 806.
} 
taken prisoner. After returning to the Union army, he was confirmed as major general in March of 1863 and was the youngest officer of that rank in the U.S. Army at that time. Captain Richard McAllister wrote of Herron:

Major General Herron, with two Divisions of Infantry and several batteries leaves here to-day to join your army. You know Frank Herron well. He commands some of the best troops in the west and they have unbounded confidence in him. No man here [St. Louis, where many Midwestern troops moved through] or in Iowa is so popular as Herron. ${ }^{18}$

That "unbounded" confidence that the soldiers had in Herron in part came from fighting along side of him as he rose through the ranks, but also from the knowledge that he was from their state. The lower-level commanders were more popular than their higher-up counterparts (with the only exception possibly being Grant himself) because they were from the same place, and fought side-by side with their troops. The Civil War troops could relate to these commanders on multiple levels. It is for this reason, also, that the conflict as a whole was much more regionally based from battle to battle.

The issue of region comes to light even more with the camaraderie that sometimes existed between the troops of the Union and the troops of the Confederacy. This is common in the traditional histories of the war, as the war put brother against brother and friend against friend. But many times, this camaraderie came from soldiers who were from the same area, who could not only relate to each other because of their experiences on the battlefield, but also because they were from the same region. These soldiers were fighting to protect their homes, their way of life, as well as what they believed in. However, they also knew that their enemy was doing the same thing. "The boys went down to them [the Confederate troops] and shake hands and had quite a talk,” Joseph Kohout of the $31^{\text {st }}$ Iowa wrote, “They gather the Rebels are quite

${ }^{18}$ John Y. Simon, The Papers of Ulysses S. Grant (Carbondale: Southern Illinois University Press, 1979), Vol. 8: 346. 
good friends." ${ }^{19}$ Outside of the war, many of these men could surely have been, if not possibly were, "good friends", and they recognized this. Some of this camaraderie and identification with each other could not have happened between Confederate Midwestern soldiers and Union Northeastern soldiers, for example, as they did not share as much of an understanding of each other or the very close bond of being from the same region.

The Iowa regiments' involvement during and around the Siege of Vicksburg is just one example of events that occurred on a more broad scale throughout the entire war. Soldiers during this Vicksburg campaign, as well as during the whole war, were incredibly versatile off the battlefield, and many unheard-of soldiers and regiments were the backbone of the war itself for the vital work they did other than fighting. No one can or will ever forget those hundreds of thousands of brave men who fought and died in those horrific and deadly battles. But history too easily forgets about those men who put in the dirty work, the less glamorous and therefore less noticed work, which was the motor that kept the war going. Without the tireless efforts of these men, like the many regiments from the state of Iowa during the Vicksburg Campaign, the war could not have occurred or continued. This was also a war of regions, just as much as it was North versus South. Oftentimes, people get lost in the generic ideas surrounding the war, like slavery and uniting the country, they become blind to the importance of family and home to many of these soldiers. Overall these soldiers fought for the Union or the Confederacy, but to many of them, the "Union" or "Confederacy" represented their way of life, those they loved, and those men fighting next to them. All of these aspects, which to many seem mundane or unimportant, combined to form a vital part of the Civil War for all soldiers and should not go unnoticed, as they do in many typical popular histories.

\section{Works Cited}

\footnotetext{
${ }^{19}$ Joseph Kohout to his father, June 1, 1863, Joseph Kohout Letters.
} 
Secondary Sources

Bearss, Edwin Cole. The Vicksburg Campaign. Vol. 3. Dayton, OH: Morningside House Inc., 1986.

Simon, John Y. The Papers of Ulysses S. Grant. Vol. 8. Carbondale, IL: Southern Illinois University Press, 1979.

\section{Primary Sources}

Giauque, James. James Giauque to Alfred Giauque, June 23, 1863. Giauque Family Papers. Civil War Collection, Special Collections Dept., University of Iowa Libraries, Iowa City, IA.

Kohout, Joseph. Joseph Kohout Letters. Civil War Collection, Special Collections Dept, University of Iowa Libraries, Iowa City, IA.

Mann, Asahel. Papers of the Mann Family. Civil War Collection, Special Collections Dept, University of Iowa Libraries, Iowa City, IA.

Russell, William A. William A. Russell to Juliet Russell, June 19, 1863. Russell Family Papers. Civil War Collection, Special Collections Dept., University of Iowa Libraries, Iowa City, IA. 